\title{
時間分解ポーラログラフ法によるビオロゲン吸着層形成過程の追跡
}

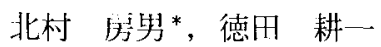

\section{Dynamic Aspect to Monolayer Formation Process of Viologen Observed by Time-Resolved Polarography}

\author{
Fusao KITAMURA* and Koichi TOKU1)A
}

Received May 21, 1996 ; Accepted July 29, 1996

\section{1 緒 言}

水銀表面には種々のイオンや有機物が強く吸着するた め、これまでそれらの吸着過程やレドックス反応の研究に 広く用いられてきた. 水銀電極には大きく分けて吊下げ電 極 (静止電極) と滴下電極がある。このうち滴下電極を用 いたポーラログラフ法では，一般に水銀の自重を利用して 滴下させるため，水銀滴が生成しはじめてから落下する瞬 間まで絶えず表面積か湾化し，それによる充電電流の笴与 を無視できない，また，表面は絶えず流動しているために 吸着層が安定化されない，従って，静止電極で見ている挙 動とは異なったものと考元るへきである，もし，こく短時 間のうちに所定の表面積にまで水銀滴を成長させること ができるならば,これらの年を克服してその後の吸着過 程のダイナミクスを追うことも可能となるであろう：この ような見地から本報告では，短時間で成辰可能な水銀電極 を利用し，これに時閭分解電流測定を組み合わせ，安定な 吸着層か形成されるまでの過程を追跡することを試みた。 ここで選んだ界面活性物質はビオロゲンである.

これまでわれわれは, 水銀電極表面でアルキルビオロゲ ン類がFig.1に示すように特異な一対の吸着波を示すこと を見出し，これを速度論的・分光学的に検剖してきた ${ }^{1,21}$. その結果, この波は吸着ビオロゲンによる一電子酸化遈元 反応

$$
\mathrm{V}^{2+} \leftrightharpoons \mathrm{V}^{+}+e^{-} \quad\left(\mathrm{V}^{\mathrm{n}+}: \text { viologen }\right)
$$

によるものであることが示されてきた。この吸着波の位置 はアルキル鎖長に大きく依存するが，また溶液内ビオロゲ

東京工業大学大学院総合理工学研究科（下226 横浜市 緑区長津田町 4259） Interdisciplinary Graduate School of Science and Engineering, Tokyo Institute of Technology (Nagatsuta, Yokohama, Japan)

Key Words ; Polarography, Viologen, Adsorption, TimeResolved Measurements

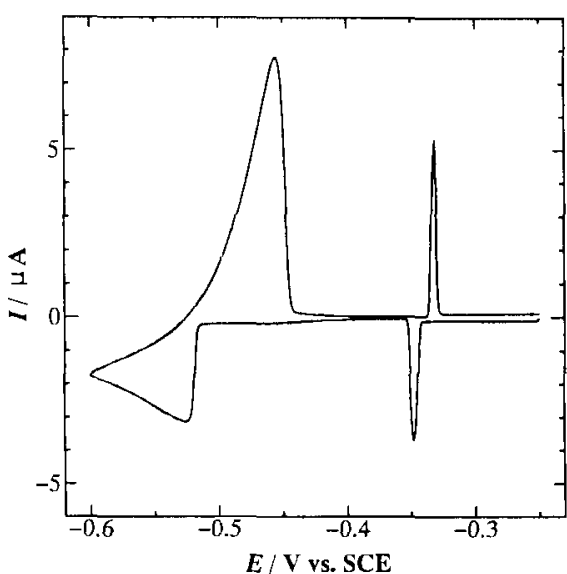

Fig. 1 Cyclic voltammogram of $1 \mathrm{mM}$ heptyl viologen in aqueous $0.1 \mathrm{M} \mathrm{KBr}$ solution obtained on a hanging mercury electrode $\left(\mathrm{M}=\mathrm{mol} \mathrm{dm}^{-3}\right)$. Sweep rate was $100 \mathrm{mV} / \mathrm{s}$.

ン濃度に応じて吸着層の構造が安定化するまで経時変化 を示すこともわかってきている。

\section{2 実 験}

用いた水銀電極はPAR303 型 $(E G \& G)$ てある. この電極 の特徽は,ソレノイドを用いた電磁弁により水銀の流量を コントロールしている点にあり，電磁弁が開いている間の み一定の流速で水銀か流出するため，Fig.2に示すように その表面秥はこく短時間（四の $\Delta t$ に相当）のうちに一定 值に達する。この水銀滴の生成・強制谪下は外部トリガー 信号により制御できる.そこでこれらをコンピューターに よりコントロールし，A/D およびD/A コンバーターを利 用して Fig.2に示す夕イムチャートに従って一定電位にお ける水銀滴生成から定常に達するまでの電流值の変化を 時間を追って記録した。なお，トリガー信号の出力から水 銀滴の生成が実際に開始さ机るまでには約 $52 \mathrm{~ms}$ の時間 僬れがあるが，以後は水銀滴生成開始時刻を $t=0$ 亡する。 


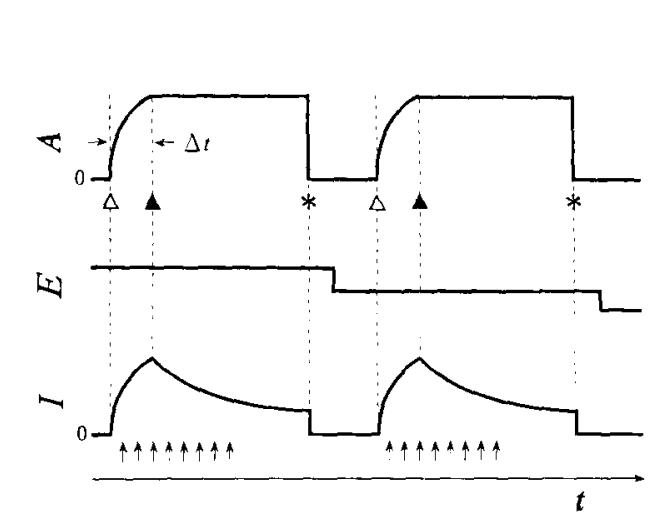

Fig. 2 Schematic illustration of the change in the surface area $(A)$, applied potential $(E)$ and the current flow $(I)$ for the DME with time $(t)$. Positions of the valve open $(\Delta)$, valve close $(\boldsymbol{\Delta})$, dislodge trigger $(*)$ and the data acquisition intervals $(\uparrow)$ are also indicated.

対極には白金線，参照極には $\mathrm{KCl}$ 飽和力ロメル電極を使 用した. 水銀は希硝酸および蒸留水で洗浄した後，真空蒸 留したものを用いた，臬化力りウ々（Wako）は特級のも のをそのまま用い，へプチルビオロゲンジブロマイド(東 京化成)はエ夕ノールから再結晶した．溶液は Milli-Q systemにより精製した超純水を用いて型製し， $N_{2}$ ガス (99.999\%)により十分脱気を行った.すへての测定は空鼬 で行った.

\section{3 結果および考察}

\section{1 支持壏のみを含む溶液の場合}

Fig.3(a)は， $0.1 \mathrm{M} \mathrm{KBr}\left(\mathrm{M}=\mathrm{mol} \mathrm{dm}{ }^{-3}\right)$ 水溶液中で測定し た時間分解ポーラログラムである，图からも明らかなよう に、滴生成開始と同時に急激に電流が流れはじめる。これ は，電気二重層の充電電流に相当するもので，水銀滴の成 長と共に，今まさに二重層が形成されつつある状態を示し ていると考えられる．Fig.3(b) は，滴成長途中における電 流の電位依存性を示したものであるが，各測定時刻で観测 される電流は，印加電位に対して単調な変化を示し，いず れの時刻でもある筪位付近 (-0.45V)でゼロを横切ってい る.この電位が p Z cに対応するものと考えられる。一方， $-210 \mathrm{mV}$ における電流の時間変化を游のサイズを変えて 測定したものが Fig.4(a)である．電流は単調に流れるので はなく，かなり䙉雑な変化を示している.特に滴の生成開 始直後上終了直前に大きな正および负の電流がいずれの サイズにおいても㷵められるが、これは電磁升開閯の際の (a)
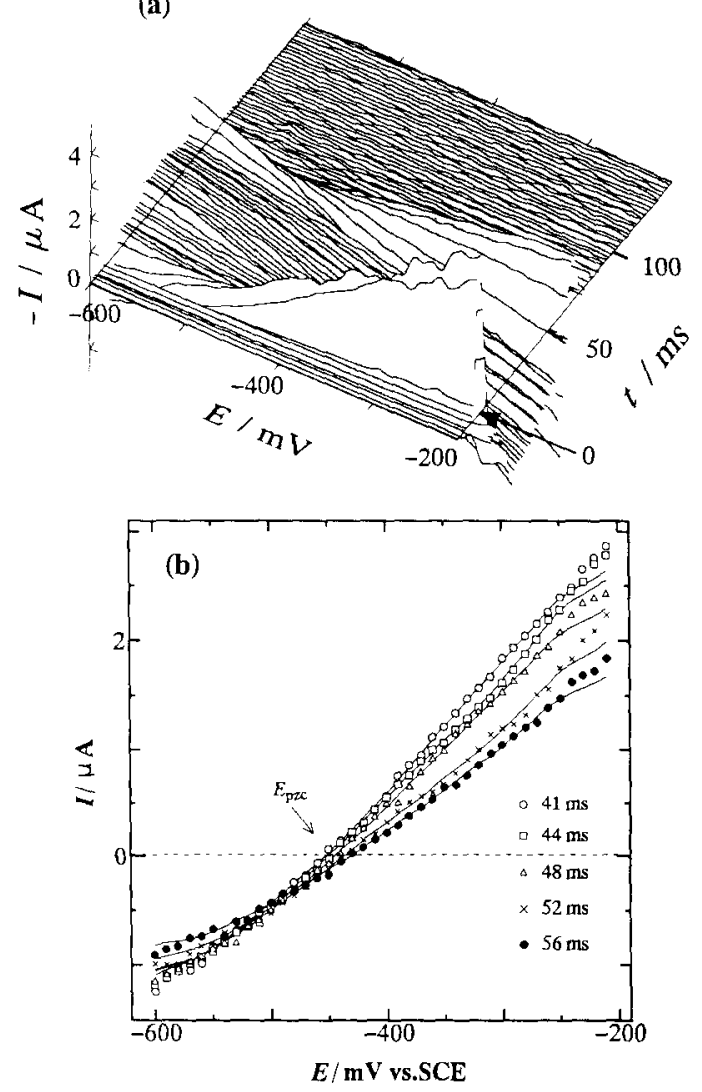

Fig. 3 (a)Time-resolved polarograms obtained in aqueous $0.1 \mathrm{M} \mathrm{KBr}$ solution. Time resolution was $5 \mathrm{~ms}$. Drop size was $S$. (b)Time dependence of the $I-E$ profiles. Drop size was $\mathrm{M}$.

キャピラリーの振動によるものである. 電流の時間皘分, すなわち界面に蓄皘された電荷は滴のサイズとよい一致 を示し， $t^{2 / 3}$ に比例する（Fig.4(b)）。これは，一定の流量 で水銀滴が成長していることを示す.

\section{2 ヘプチルビオロゲンを加えた䭪合}

Fig.5(a), (b) はヘプチルビオロゲンをそれぞれ $0.1 \mathrm{mM}$ および $1 \mathrm{mM}$ 添加した場合に得られた時間分解ポーラロ グラムである.先に述べた支持塩のみの場合と比へて特に 舆味深いのは，二重層形成直後に一度鋭い波形が $-500 \mathrm{mV}$ 付近に現れ，これがその後約 $50 \mathrm{~ms}$ の間に $-350 \mathrm{mV}$ 付近 まで正側にシフトするが,ここで一旦ブロードな波となっ てその後再び狭くなってくることである. Fig.5(a)で最終 的にCVで観測されるのと同じ位置および形状となるの 

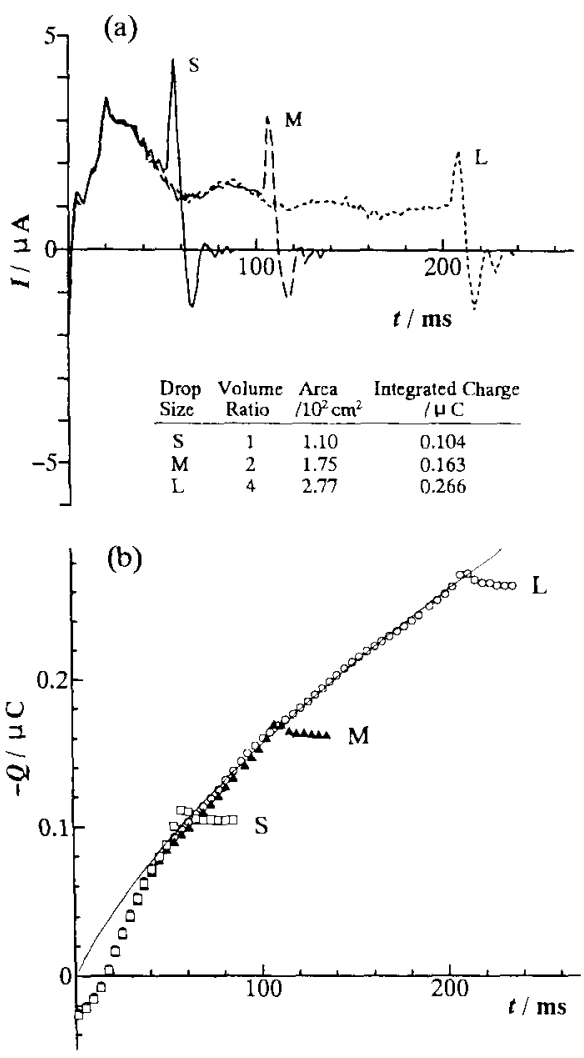

Fig. 4 (a) $I-t$ curves measured at $-210 \mathrm{mV}$ in the same solution. Letters $S, M$ and $L$ indicate the drop sizes.

(b) Integrated charge $Q$ vs. $t$ curves of Fig. 3(a)

は二重層形成後の䄪 $t=300 \mathrm{~ms}$ 付近であることがわかる. このような襩雑な変化が何を意味しているのか, 現在検討 を進めている.

一方(b)では，二重層の形成がまだ終わらないうちから 既にCVで観測されるのとほぼ同じ位置に鋭い波が現れ てきている.このことは，ビオロゲンの吸着が桩散律速で 起こっており，1 mM 程度の濃度ではほ上んど瞬時(数 $\mathrm{ms}$ 以内)に安定な構造が形成されてしまうことを示している. なお，二重層形成完了直後の $t=90 \mathrm{~ms}$ 付近に不連続な部 分が見られるが,これはキャピラリーの振動が原因である と考えられる。また， $-500 \mathrm{mV}$ からの電流の立ち上がりは， 主波の 1 電子逼元反応 (1 式) に対応し，ここで電極上に ラジカルカチオン塩による紫色の多層膜が析出してくる.

このように，時間分解湘定を行うことにより，静止電極 上での CV 测定のみからでは解らなかった吸着層形成の ダイナミックな遇程を追跡できる可能性が示された。この

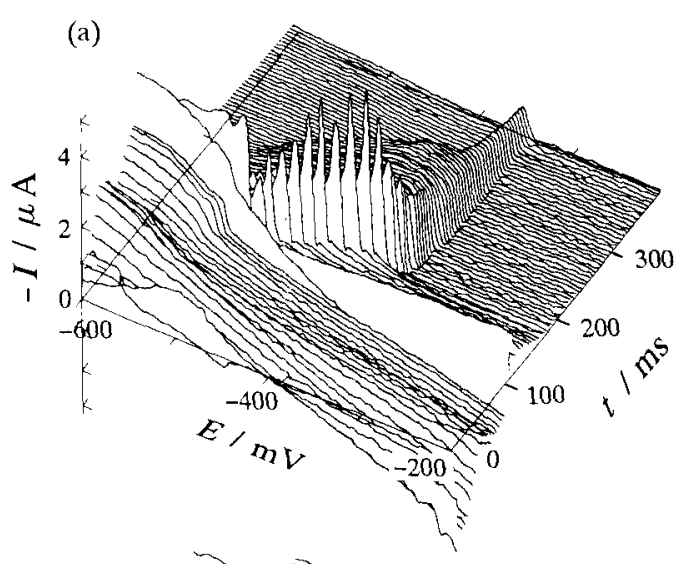

(b)

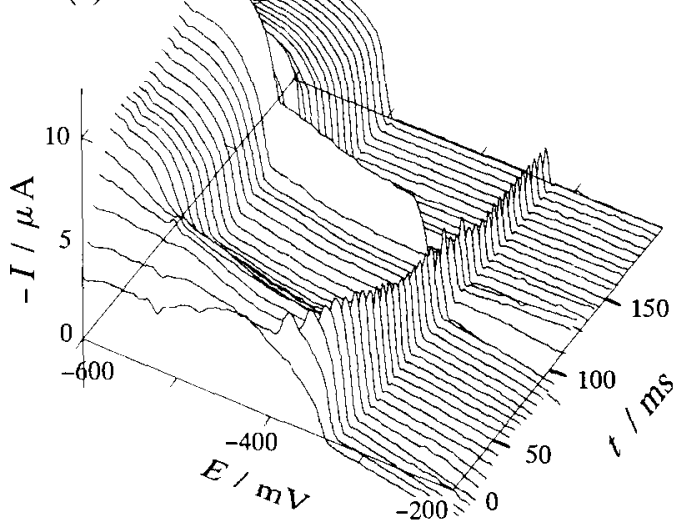

Fig. 5 Time-resolved polarograms obtained in $0.1 \mathrm{M} \mathrm{KBr}$ solution with (a) $0.1 \mathrm{mM}$ and (b) $1 \mathrm{mM}$ heptyl viologen. Time resolution was $5 \mathrm{~ms}$. Drop size was $\mathrm{M}$.

ような測定が可能であるのも，容易に表面を更新すること のできる水銀電極ならではの利点であり，また上記測定法 は吸着系に限らず，化学反応を伴った溶液内レドックス反 応などに適用した場合,さらなる有益な情報を与える可能 性もあるもの上考えられる。

\section{文 献}

1) F. Kitamura, T. Ohsaka and K. Tokuda, J. Electroanal. Chem., 347, 371 (1993)

2) F. Kitamura, T. Ohsaka and K. Tokuda, J. Electroanal. Chem., 353, 323 (1993) 